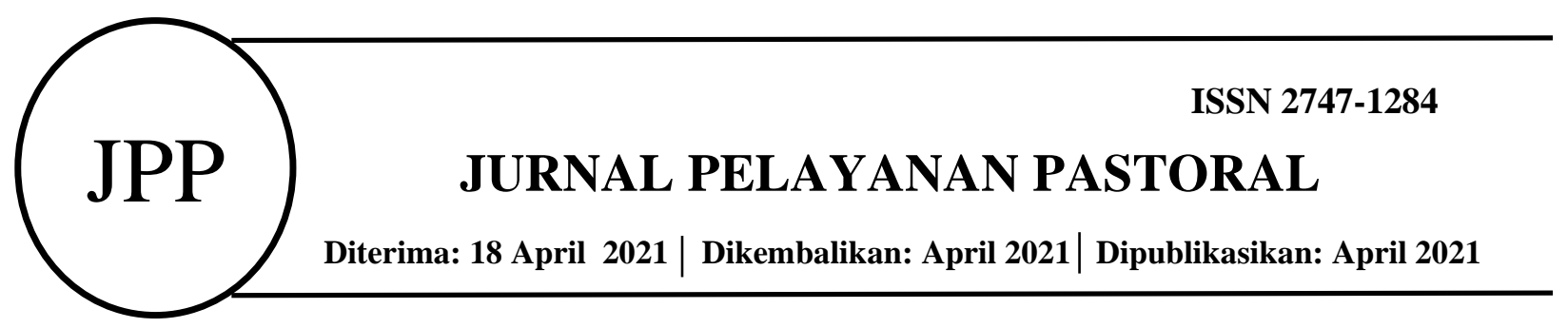

\title{
WAJAH BARU BINA IMAN ANAK KATOLIK (BIAK) SELAMA MASA PANDEMI COVID-19
}

\author{
Chrystian Loudry Malau*1, Antonius Denny Firmanto*2, Nanik Wijiyati Aluwesia*3 \\ ${ }^{1,2,}{ }^{3}$ Sekolah Tinggi Filsafat Teologi Widya Sasana, Malang \\ email: 1'chrystianmalau5767@gmail.com¹,2rm_deni@yahoo.com, ${ }^{3}$ nanikwa9@gmail.com
}

\begin{abstract}
Abstrak
Kehadiran pandemi covid-19 telah membawa pengaruh yang besar bagi kehidupan manusia, khususnya Gereja sendiri. Bagi Gereja sendiri, Pengaruh yang dirasakan adalah Gereja dibawa kepada kebijakan mengubah pelayanan pastoralnya yang biasanya secara tatap muka, kini menggunakan media daring atau online. Akibat dari kebijakan ini adalah kegiatan umat beriman menjadi terhambat. Salah satu aktivitas umat beriman yang menjadi dampak munculnya pandemi Covid-19 adalah Bina Iman Anak Katolik (BIAK). Sejak masa pandemi, BIAK yang biasanya dilakukan secara tatap muka, kini berubah menjadi BIAK secara online. Kegiatan ini telah dilakukan oleh Paroki St. Perawan Maria dari Gunung Karmel, Malang. Perubahan yang terjadi menandakan bahwa Gereja memiliki sikap mendengarkan, khususnya pada masa pandemi Covid-19. Situasi ini membawa wajah baru BIAK yaitu BIAK online yang semakin modern.
\end{abstract}

Kata Kunci: Pandemi Covid-19, Gereja, BIAK, Internet, Mendengarkan.

\begin{abstract}
The presence of the Covid-19 pandemic has had a major impact on human life, especially the Church itself. For the Church itself, the perceived influence is that the Church has been led to a policy of changing its pastoral ministry, which is usually face-to-face, now using online or online media. The result of this policy is that the activities of the faithful become obstructed. One of the activities of the faithful that has been impacted by the emergence of the Covid-19 pandemic is Catholic Child Development (BIAK). Since the pandemic era, BIAK, which is usually done face-to-face, has now changed to BIAK online. This activity has been carried out by the St. Parish. The Virgin Mary from Mount Karmel, Malang. The changes that have occurred indicate that the Church has a listening attitude, especially during the Covid-19 pandemic. This situation brings a new face to BIAK, namely BIAK online which is increasingly modern.
\end{abstract}

Keywords: The Covid-19 pandemic, Church, BIAK, Internet, listening. 


\section{PENDAHULUAN}

Munculnya virus Covid-19 membawa dampak yang besar bagi setiap sektor kehidupan manusia. Kehidupan manusia dengan segala mobilitasnya kini mengalami gangguan. Hal ini karena berdasarkan penelitian, virus ini merupakan penyakit menular yang menyebar melalui kontak jarak dekat, orang ke orang melalui pernapasan dari percikan batuk atau napas (droplets). Dengan demikian, kehidupan manusia yang bergerak, berelasi dan berinteraksi dengan sesama terpaksa harus dikurangi.

Saat ini, Virus Corona menjadi bencana global. Hal ini karena virus ini memiliki sifat penyebaran yang sangat cepat, sehingga menyebar ke seluruh dunia (pandemi). Selain itu, berdasarkan penelitian, virus ini merupakan virus dalam kategori baru, sehingga belum ditemukan obat yang benar-benar ampuh untuk mengatasinya. Berdasarkan hal ini, pemerintah di seluruh dunia, khususnya pemerintah Indonesia berusaha untuk memutus rantai penyebarannya virus ini melalui kebijakan protokol kesehatan. Di dalam protokol kesehatan tersebut, terdapat ketentuan untuk menjaga jarak, memakai masker, mencuci tangan, menjauhi kerumunan, dan mengurangi mobilitas.

Gereja menyadari bahwa keberadaannya tidak dapat dipisahkan dari dunia. Dengan begitu, persoalan yang dihadapi di dunia, khususnya mengenai pandemi Covid-19 juga merupakan persoalan Gereja juga. Sebagai bukti kehadiran Gereja di dunia, Gereja berusaha memperlihatkan kepeduliannya untuk mendukung dan mengikuti pedoman protokol kesehatan yang diterapkan oleh pemerintah.

Kebijakan yang diambil oleh Gereja saat ini di satu sisi merupakan kebijakan yang baik. Hal ini karena dapat membantu pemerintah untuk memutus rantai penyebaran Covid-19 di dalam masyarakat, khususnya dilingkungan Gereja sendiri. Akan tetapi di sisi lain, kebijakan ini membawa dampak negatif pada umat, yaitu terhambatnya aktivitas Komunitas Basis Gerejani untuk melakukan kegiatan imannya di dalam Gereja.

Sikap Gereja yang terbuka dan mendengarkan situasi dunia, khususnya di masa pandemi ini membawa Gereja untuk sementara waktu mengubah cara berpastoral. Pastoral yang biasanya diakukan Gereja secara tatap muka, kini dilakukan tanpa harus bertemu secara langsung, yaitu dengan terhubung dalam jaringan internet (online). Wujud nyata sikap mendengarkan Gereja ini adalah terbentuknya banyaknya program yang memanfaatkan media digital atau media online .

Melalui tulisan ini, penulis hendak mengajak pembaca untuk melihat salah satu kegiatan pastoral Gereja yang menjadi dampak kehadiran virus Covid-19. Kegiatan tersebut adalah pastoral kategorial Bina Iman Anak (BIAK). Berdasarkan kegiatan tersebut, penulis hendak menyajikan kepada pembaca bagaimana kegiatan BIAK itu, tujuan BIAK, subyek BIAK, dasar BIAK, apa dampak Covid-19 bagi BIAK, khususnya bagi kelompok kategorial BIAK Paroki St. Perawan Maria dari Gunung Karmel, Malang, dan bagaimana media online berperan dalam kegiatan Bina Iman Anak Katolik (BIAK) di paroki tersebut. Tujuan dari tulisan ini adalah untuk memberikan gagasan baru mengenai wajah baru BIAK pada masa pandemi Covid-19.

\section{METODE PENELITIAN}

Metode penelitian yang digunakan penulis adalah menggunakan metode kualitatif dalam bentuk eksplorasi kepustakaan, kemudian menghubungkannya dengan studi kasus kegiatan Bina Iman Anak Katolik (BIAK) di Paroki St. Perawan Maria dari Gunung Karmel, Malang. Menurut Albi, penelitian kualitatif adalah pengumpulan data pada suatu latar alamiah dengan maksud menafsirkan fenomena yang terjadi di mana peneliti adalah sebagai instrumen kunci, pengambil sampel sumber data dilakukan secara purposive dan snowbaal, teknik pengumpulan dengan 
gabungan, analisis data bersifat induktif/kualitatif, dan hasil penelitian kualitatif menekankan makna dari pada generalisasi (Anggito, 2018). Selanjutnya menurut Zed, penelitian kepustakaan merupakan serangkaian kegiatan yang berkenaan dengan pengumpulan data Pustaka, membaca, dan mencatat serta mengolah bahan penelitian (Zed, 2014). Sugiyono menambahkan bahwa penelitian kepustakaan merupakan penelitian yang bersifat mengkaji secara teoritis, setiap fenomena yang berkaitan dengan budaya, nilai dan norma yang berkembang. Pengumpulan data yang dilakukan pada penelitian ini diperoleh dari berita dan artikel pada portal berita online yang terpercaya, selain itu juga menggunakan jurnal publikasi yang relevan dengan tujuan penelitian (Sugiyono, 2013).

Berdasarkan metode penelitian di atas, penulis menggunakan kelompok kategorial Bina Iman Anak Katolik (BIAK), Paroki St. Perawan Maria dari Gunung Karmel, Malang, sebagai obyek penelitian. Berdasarkan objek penelitian tersebut, penulis pertama-tama melakukan teknik pengumpulan data mengenai bagaimana kegiatan BIAK itu, melalui eksplorasi sumber literatur, seperti buku, jurnal, dan sumber-sumber lainnya, dan kemudian menghubungkannya dengan obyek kasus penelitian, yaitu BIAK Paroki St. Perawan Maria dari Gunung Karmel, Malang. Berdasarkan obyek penelitian itu juga, penulis melakukan teknik pengumpulan data melalui wawancara dan juga membagikan kuesioner. Wawancara dilakukan dengan menggunakan aplikasi WhatsApp dan kuesioner dibagikan dengan menggunakan bantuan Google Form untuk membuat kuesioner online . Google Form adalah inovasi baru dari sebuah layanan yang dirancang untuk memudahkan proses validasi data atau informasi (Sudaryo dkk, 2019). Melalui wawancara dan kuesioner online tersebut, penulis menyertakan pertanyaan-pertanyaan yang berhubungan dengan kegiatan BIAK. Tujuan dari pertanyaan ini adalah sebagai data yang digunakan untuk menjawab pertanyaan yang menurut penulis menarik untuk dibahas, yaitu: bagaimana sejarah, tujuan, subyek utama BIAK.

Data yang diperoleh dari WhatsApp dan kuesioner online tersebut juga Google Form tersebut, penulis menyertakan pertanyaan-pertanyaan yang berhubungan dengan kegiatan Bina Iman Anak Katolik. Tujuan dari pertanyaan ini adalah untuk melihat kegiatan BIAK sebelum pandemi covid-19 dan pada masa pandemi Covid-19. Jawaban dari pertanyaan itu kemudian dirumuskan untuk menjawab pertanyaan penelitian ini, yaitu bagaimana kegiatan BIAK, tujuan BIAK, subyek BIAK, dasar BIAK, apa dampak Covid-19 bagi BIAK, bagaimana media online berperan dalam kegiatan Bina Iman Anak Katolik (BIAK). Tujuan dari tulisan ini adalah untuk memberikan gagasan baru mengenai wajah baru BIAK pada masa pandemi Covid-19.

\section{HASIL DAN PEMBAHASAN \\ Pandemi Covid-19 dan Gereja}

Munculnya virus Corona atau dikenal juga dengan nama Covid-19 membawa pengaruh yang besar di dalam kehidupan manusia. Banyak bidang mengalami dampak dari virus Covid-19 ini, yang kemudian ditetapkan oleh WHO (World Health Organization) menjadi pandemi. Pandemi adalah skala penyebaran penyakit yang terjadi secara global di seluruh dunia (Rehia Sebayang, 2020). Dampak yang paling dirasakan dari pandemi ini adalah dalam bidang ekonomi. Sejak munculnya virus ini, sektor ekonomi di seluruh negara dan juga di Indonesia semakin mengalami krisis.

Selain itu, kemunculan pandemi juga mengarahkan manusia kepada "New Normal". New normal adalah sebuah perubahan budaya hidup yang dicanangkan pemerintah Republik Indonesia agar masyarakat dapat terbiasa dengan tatanan hidup normal yang baru untuk menghadapi penyebaran virus Corona (Utami, 2020). Di dalam new normal, terdapat kebijakan protokol 
kesehatan yang harus ditaati, yaitu menjaga jarak (Phyisical Distancing), memakai masker, mencuci tangan, menjauhi kerumunan, dan mengurangi mobilitas (protokol 5M). Dampak dari protokol kesehatan ini adalah manusia diwajibkan untuk beraktivitas atau bekerja di rumah (work from home) sampai situasi mulai membaik. Semuanya itu dilakukan sebagai usaha agar penyebaran dan penularan virus Corona-19 tidak semakin meningkat.

Munculnya Covid-19 juga mempengaruhi kehidupan Gereja. Kehadiran Covid-19 membawa Gereja-gereja di seluruh dunia untuk terus mencari cara yang terbaik dalam membantu menghentikan penyebaran virus corona (Diseko, 2020). Gereja Katolik sendiri kemudian dibawa untuk mengambil kebijakan, yaitu mengikuti pedoman pemerintah untuk menerapkan protokol kesehatan di lingkungan Gereja.

Kebijakan ini di satu sisi merupakan kebijakan yang baik. Hal ini karena dapat membantu pemerintah untuk menekan perkembangan dan penyebaran Covid-19 di dalam masyarakat, khususnya dilingkungan Gereja sendiri. Akan tetapi di sisi lain, kebijakan ini membawa dampak pada umat, yaitu terganggunya proses pelayanan, pengajaran, pendalaman, dan pendidikan iman di dalam Gereja, khususnya kepada anak-anak. Dengan kata lain, kebijakan ini membawa efek terhambatnya berbagai aktivitas kehidupan umat beriman di dalam Gereja.

Apabila Gereja terus bertahan dalam kebijakan ini, maka Gereja akan kehilangan umatnya satu persatu. Bukan hanya itu saja, Gereja mungkin akan hilang dari muka bumi, sebab Gereja dimengerti bukan hanya merujuk bangunan fisik saja, tetapi juga merujuk pada persekutuan umat Allah. Persoalan ini bukanlah persoalan yang biasa. Gereja harus mencari alternatif lain untuk terus dapat melakukan pelayanannya kepada umat.

\section{BIAK (Bina Iman Anak Katolik)}

Salah satu aktivitas umat beriman yang terdampak dengan munculnya virus Covid-19 ini adalah kegiatan kategorial BIAK. BIAK merupakan singkatan dari Bina Iman Anak Katolik. Istilah serupa yang digunakan di beberapa Keuskupan untuk menyebut BIA dikenal sebagai PIA (Pembinaan/Pendampingan Iman Anak), Anak sekolah Minggu (ASMIKA), Minggu Gembira, Sekolah Minggu dan lain sebagainya. Kata Sekolah Minggu” Berasal dari bahasa Inggris "Sunday School'. Sunday memiliki arti hari pertama dalam minggu, hari istirahat dan hari bagi orang Kristiani untuk melaksanakan perayaan peribadatan; School memiliki arti lembaga formal yang menangani suatu pendidikan. Apabila kedua kata ini digabungkan, maka memiliki makna suatu kegiatan yang dihadiri oleh anak-anak dan pelaksanaannya berlangsung di Gereja dengan tujuan untuk mengikuti pelajaran Agama (bdk. Pusat Kateketik, 2002).

Istilah atau Sebutan yang berbeda yang digunakan di beberapa keuskupan, dengan maksud untuk menyebut kegiatan pendampingan iman anak ini, sangat dipengaruhi oleh berbagai kesan atau pengalaman tertentu terkait dengan Bina Iman Anak Katolik (BIAK). Sebutan ini pada umumnya muncul berdasarkan empat alasan, yaitu: 1. Peserta yang dihadapi adalah kelompok usia anak-anak kecil yang beragama Katolik; 2. bentuk, materi dan metode pembinaannya sama seperti di sekolah, tetapi terdapat beberapa perbedaan yaitu dalam hal waktu yang menggunakan hari minggu dan tempat pembinaan yang biasanya digunakan di lingkungan gereja; 3. Suasana pembinaan yang lebih menekankan suasana ceria dan gembira; 4. Penekanan terdapat pada aspek pembinaan, pendampingan, dan pengajaran iman (Tse, 2014).

\section{Tujuan BIAK}

Tujuan utama dari BIAK adalah agar anak-anak dapat memiliki sikap dan wawasan iman kristiani, dan mampu mengungkapkan imannya, serta dapat mewujudkan imannya sesuai dengan 
usia mereka. Selain itu, tujuan kegiatan BIAK adalah sebagai salah satu bentuk usaha Gereja untuk membantu keluarga dalam mengembangkan iman anak. Hal ini dilakukan Gereja karena menyadari bahwa di dalam keluarga lahirlah warga-warga baru Gereja, yang diterima melalui berkat rahmat Roh Kudus karena dibaptis, dan diangkat menjadi anak-anak Allah (art. 11) (Dokumen Konsili Vatikan II, 1990). Dengan kata lain, kegiatan BIAK juga di lihat sebagai wadah perpanjangan tangan Gereja Katolik dalam tugas perutusannya di dunia, yang diwujudkan pada anak-anak melalui pembinaan anak. Tujuannya adalah agar anak-anak semakin menyadari bahwa Yesus sebagai Tuhan dan juru selamat manusia, dan juga juru selamatnya. Dengan begitu, BIAK dapat diartikan sebagai suatu wadah pelayanan, dari, oleh dan untuk Gereja yang bergerak dalam pelayanan iman bagi anak-anak usia dini (Tse, 2014).

\section{Subyek BIAK}

Subyek utama dari kegiatan BIAK adalah anak itu sendiri. Hal ini karena Gereja melihat bahwa anak-anak merupakan generasi penerus Gereja di masa yang akan datang. Sebagai penerus Gereja di masa yang akan datang, tentunya mereka akan bersinggungan dengan lingkungan sekitar atau lingkungan masyarakat. Agar dapat turut andil di dalam lingkungan masyarakat, maka Gereja menjadikan anak sebagai subyek yang harus di didamping. Melalui usaha itu, diharapkan dapat membantu anak untuk memupuk rasa tanggung jawab sebagai anggota Gereja dan juga sebagai anggota masyarakat.

Usia anak yang menjadi subyek BIAK adalah 1-12 tahun (Bagiyowinadi, 2009) Selanjutnya, Paus Yohanes Paulus II melalui dokumen Catechesi Tradendae artikel 37 menegaskan bahwa anak-anak yang telah menerima baptisan bayi pun adalah sasaran pendampingan iman untuk melengkapi proses inisiasi dan benih iman dalam pembaptisan itu makin bertumbuh kembang dan berbuah dalam kesaksian hidup dengan cara pendampingan (Paulus II, 2006).

\section{Dasar Pembentukan BIAK}

Gereja menyadari bahwa kehidupan kaum muda, khususnya anak-anak perlu untuk mendapatkan perhatian. Hal inilah yang mendorong Gereja untuk membentuk kelompok kategorial Bina Iman Katolik. Pembentukan kelompok ini bermaksud agar anak-anak semakin bertumbuh baik di dalam iman, bertumbuh dalam kehidupan pribadi, sosial, dan panggilan hidupnya. Pembentukan kelompok BIA ini juga memiliki beberapa dasar, yaitu dasar Kitab Suci, dan dokumen Gereja.

Di dalam Kitab Suci, terdapat banyak teks yang dapat dijadikan rujukan untuk melihat pengajaran Yesus tentang anak-anak. Salah satunya yang dapat dijadikan rujukan adalah melalui Injil Lukas 18:15-17. Berdasarkan teks itu, Yesus mengajarkan bahwa anak-anak adalah Gambaran Kerajaan Surga. Di dalam teks ini Yesus mau menunjukkan bahwa anak-anak mendapat tempat istimewa dalam diri Yesus. Keistimewaan ini terlihat jelas dari sikap Yesus yang mengundang anak-anak untuk datang kepada Yesus. Bukan hanya itu saja, anak-anak juga dijadikan sebagai model bagi mereka yang menanggapi pewartaan Yesus. Teks ini menjadi dasar ajaran Yesus bahwa anak-anak penting untuk diperhatikan. Semua murid-Nya memiliki kewajiban untuk memberikan jalan dan petunjuk yang benar bagi anak-anak. Bina iman anak juga merupakan sarana untuk mengembangkan religiositas yang menjadikan anak semakin menghayati iman dan menjadikan anak lebih bertanggungjawab, (Selatang, 2020).

Gereja melalui dokumen Lumen Gentium artikel 11 menyatakan kesadarannya bahwa di dalam keluarga lahirlah warga-warga baru Gereja, yang diterima melalui berkat rahmat Roh Kudus 
karena dibaptis, dan diangkat menjadi anak-anak Allah (Dokumen Konsili Vatikan II, 1990). Melalui dokumen ini, Gereja secara tidak langsung mau mengatakan bahwa keluarga memiliki peran penting di dalam pembinaan iman anak. Hal ini karena keluarga merupakan tempat pertama dan utama dalam pendampingan iman anak. Di dalam keluarga, anak-anak mengalami nila-nilai kehidupan, dan nilai-nilai Kristiani. Oleh karena itu, keluarga memiliki kewajiban untuk mengusahakan pendidikan anak, secara khusus dalam hal iman. Kewajiban ini merupakan perwujudkan konkret dari janji yang diucapkan orang tua kepada Tuhan melalui sakramen perkawinan, yaitu untuk mendidik anak-anak menurut iman Katolik. Selain itu Gereja melalui Konsili Vatikan II juga menegaskan tugas dan tanggung jawab keluarga sebagai pendidik tersebut. Isinya adalah sebagai berikut:

"Karena orang tua telah menyalurkan kehidupan kepada anak-anak, orang tua terikat kewajiban amat serius untuk mendidik anak-anak mereka. Maka orang tua harus diakui sebagai pendidik yang pertama dan utama bagi anak-anak mereka. Begitu pentinglah tugas mendidik itu, sehingga bila diabaikan, sangat sukar pula dapat dilengkapi. Sebab merupakan kewajiban orang tua menciptakan lingkungan keluarga, yang diliputi semangat bakti kepada Allah dan kasih sayang terhadap sesama sedemikian rupa sehingga menunjang keutuhan pendidikan pribadi dan sosial anak-anak mereka" (art. 3) (Dokumen Konsili Vatikan II, 1992).

Melalui dokumen di atas, Gereja mau menekankan kepada orang tua bahwa sudah seharusnya menyediakan waktu bagi anak-anaknya untuk membentuk mereka menjadi pribadi yang mengenal dan mengasihi Allah dan sesamanya. Selanjutnya, hak dan kewajiban orang tua untuk mendidik anak, tidak boleh digantikan sepenuhnya atau dialihkan kepada orang lain, sebab terdapat keunikan hubungan cinta antara orang tua dan anak-anak. Singkatnya, tugas mendidik anak-ini tidak dapat digantikan ataupun tidak dapat dicabut oleh siapa pun (Bdk. art. 36) (Paulus II, 2004).

Dalam Gereja-Keluarga itu, hendaknya orang tua dengan perkataan maupun teladan menjadi pewarta iman pertama bagi anak-anak mereka. Orang tua juga wajib memelihara panggilan mereka masing-masing, secara istimewa panggilan rohani. Anak mengenal imannya pertama-tama melalui keluarga. Dengan begitu, orang tua memiliki peran yang penting dalam mengembangkan iman Anak. Hal ini karena

\section{Ciri Khas BIAK}

Kegiatan Bina Iman Anak Katolik memiliki ciri khas. Ia memiliki ciri khas yang berbeda dari sekolah normal. Perbedaan ini terletak pada suasana yang diciptakan di dalam kegiatan ini. Suasana yang dimaksudkan di sini adalah suasana gembira. Seperti yang diketahui banyak orang, suasana Gembira sudah melekat di dalam diri anak-anak. Suasana gembira ini penting dan perlu untuk diciptakan, agar anak-anak merasa nyaman dan selalu ingin berkumpul dengan teman-teman, pendamping/pembinanya. Dengan begitu, BIAK menjadi semakin menggembirakan dan warta gembira Yesus Kristus semakin tersampaikan dalam kegiatan itu (Maria Goretti Sugiarti AK, 1999). Selain memiliki ciri khas di atas, kegiatan BIAK juga memiliki sifat yaitu: Yesus Kristus sebagai pusat, menjemaat, dan terbuka.

Yesus Kristus merupakan pusat kehidupan orang Kristiani. Berdasarkan hal itu, maka setiap kegiatan umat beriman seperti pembinaan dan pengembangan iman haruslah senantiasa berpusat pada diri Yesus Kristus. Apabila dikaitkan dengan BIAK, maka pendampingan iman anak juga harus didasarkan pada Yesus Kristus. Singkatnya, kegiatan BIAK memiliki sifat, yaitu Yesus Kristus menjadi pusat utama. 
Dalam kegiatan BIAK, anak-anak di latih untuk belajar berkomunikasi dengan temantemannya. Melalui pengalaman ini, anak-anak juga diharapkan dapat menumbuhkan minat mereka terhadap lingkungan Gereja dan masyarakat di mana anak itu tinggal (Pusat Kateketik, 2002). Tujuannya adalah agar anak memiliki kebiasaan untuk hidup bersama dengan teman-temannya dan umat beriman lainnya (jemaat). Selanjutnya adalah sifat terbuka. Berdasarkan sifat terbuka ini, anak-anak diajak untuk memiliki kepribadian yang terbuka. Kepribadian terbuka ini bukan hanya terbuka kepada orang tua, tetapi terbuka juga kepada para pembina, teman atau peserta BIAK dan juga terbuka kepada umat beriman lainnya.

\section{Berbagai Metode BIAK}

Kegiatan BIAK memiliki banyak macam metode. Metode yang biasanya digunakan adalah mengajak anak-anak untuk menyanyi bersama, bermain, mendengarkan cerita, berdoa kegiatan kreativitas, kunjungan karya wisata dan lain sebagainya. Penggunaan metode ini diharapkan dapat membantu anak-anak untuk mengenak Yesus Kristus dan kehendak-Nya pada usia dini. Singkatnya, metode pembinaan iman anak adalah sebuah cara atau jalan yang dipakai untuk mencapai tujuan pembinaan iman anak, yaitu mengenal Tuhan Yesus dan kehendak-Nya (Tse, 2014).

\section{Internet: Wujud nyata Gereja Yang Mendengarkan}

Gereja telah lama memberikan perhatiannya kepada internet, khususnya dalam komunikasi sosial. Gereja memandang Internet sebagai penemuan teknologi yang mengagumkan. Hal ini karena melalui internet, manusia dapat dibantu untuk memenuhi kebutuhan-kebutuhannya. Selain itu, Gereja memandang internet sebagai anugerah-anugerah Allah, sesuai penyelenggaraan ilahi. Hal ini karena melalui internet, manusia dibawa kepada persatuan dalam ikatan persaudaraan, agar menjadi teman sekerja dalam rencana-rencana penyelamatan-Nya (art. 2) (Prasasti, 2019).

Gereja meyakini bahwa melalui internet, pewartaan Injil dapat dilangsungkan. Hal ini dilatarbelakangi oleh ketersediaan akses langsung yang dapat di akses oleh setiap orang ke sumber-sumber penting religius dan spiritual. Maksudnya, setiap orang dapat mengakses informasi mengenai dokumen-dokumen penting Gereja seperti Magisterium, tulisan para Bapa dan Doktor Gereja, serta kebijaksanaan religius berabad-abad. Dengan begitu Gereja melihat peluang bahwa internet dapat digunakan sebagai sarana evangelisasi dan katekese. Bentuk perhatian dan keyakinan Gereja dengan internet mau menyatakan bahwa Gereja memiliki sikap yang mendengarkan.

Gereja juga memiliki sikap yang mendengarkan pada masa pandemi covid-19. Sikap mendengarkan Gereja itu diwujudkan dengan cara mengubah pelayanan pastoral yang biasanya diakukan secara tatap muka, kini dilakukan tanpa harus bertemu secara langsung, yaitu dengan terhubung dalam jaringan internet. Wujud nyata sikap mendengarkan Gereja ini adalah dengan terbentuknya program seperti katekese webinar, renungan daring atau memanfaatkan jaringan media sosial, serta perayaan liturgi Ekaristi yang disiarkan melalui live streaming. Semua program tersebut dilakukan Gereja dengan harapan dapat tetap menjawab kebutuhan situasi dunia, dan umat beriman khususnya orang muda yang sangat akrab dengan internet. Dengan demikian, internet merupakan salah satu cara yang dapat dilakukan agar aktivitas kehidupan umat beriman tetap berjalan. 


\section{Wajah Baru BIAK: BIAK Online}

Gereja Katolik menyadari bahwa anak-anak merupakan generasi penerus Gereja di masa yang akan datang. Gereja berharap bahwa anak-anak dapat berperan aktif dalam karya pewartaan Injil di tengah kehidupan masyarakat. Akan tetapi harapan itu kelihatannya tidak dapat berjalan dengan mulus. Hal ini karena sejak munculnya covid-19, proses BIAK tidak berjalan dengan baik.

Meskipun begitu, Gereja menyadari bahwa terdapat peluang yang dapat digunakan untuk mengatasi kesulitan itu. Peluang itu berada pada kemajuan teknologi jaringan internet. Dengan menggunakan kemajuan teknologi ini, proses kegiatan BIAK dapat dilangsungkan secara daring /Online , tanpa perlu bertatap muka secara langsung. Salah paroki yang telah mewujudkan peluang ini menjadi nyata adalah paroki St. Perawan Maria dari Gunung Karmel, Malang.

Berikut ini data-data yang diperoleh dari kegiatan BIAK di Paroki St. Perawan Maria dari Gunung Karmel, Malang, sebelum pandemi Covid-19. Jumlah anggota BIAK Paroki St. Perawan Maria Dari Gunung Karmel, Malang adalah sebanyak 40 orang, yang terdiri dari 15 peserta/ anak laki-laki dan 25 peserta/anak perempuan. Kegiatan ini dilaksanakan pada hari minggu, yaitu setiap minggu pertama sampai dengan minggu ketiga. Pada minggu keempat, kegiatan BIAK diliburkan, agar peserta BIAK mendapat kesempatan untuk mengalami kebersamaan dengan orangtua. Apabila dalam bulan itu memiliki minggu kelima, maka pada hari minggu kelima, peserta BIAK dapat mengadakan misa bersama dengan orangtuanya.

Waktu berlangsungnya kegiatan sekitar 1 jam 30 menit. Akan tetapi pada perayaanperayaan tertentu, kegiatan BIAK ini bisa berlangsung selama dua jam. Setiap melangsungkan kegiatan, peserta atau anak-anak yang hadir adalah setengah dari jumlah keseluruhan. Dengan kata lain sekitar 20 orang anak. Akan tetapi pada momen-momen tertentu seperti perayaan natal, paskah, dan libur, peserta dapat melebihi dari jumlah tetap (40 orang). Hal ini karena banyaknya perantau (anak bersama dengan orang tuanya) melaksanakan ibadah di paroki ini.

Proses kegiatan BIAK biasanya di dampingi oleh enam Orang dengan sistem bergantian dari Suster Novisiat H. Carm, Suster PIJ, Frater, dan pembina awam. Menurut pembina, kendala yang dihadapi setiap kali melangsungkan kegiatan BIAK ini adalah banyaknya orang tua yang berhalangan (sibuk) untuk mengantarkan anaknya ke tempat BIAK berlangsung. Selain itu, ada juga orang tua yang tidak mengetahui pukul berapa berlangsungnya kegiatan BIAK ini. Alasan lain yang ditemui adalah jarak rumah anak yang jauh dengan tempat berlangsungnya kegiatan BIAK.

Struktur kegiatan BIAK dilakukan dengan mengikuti pola antara lain: Sapaan awal, gerak dan lagu pembuka, doa pembukaan, bacaan Injil (mengikuti bacaan Injil pada hari itu), renungan, aktivitas/kreativitas (yang mengacu pada catatan signal) (Hadi, 2021), sapaan penutup, berkat imam, dan lagu penutup.

Setiap kali mengadakan kegiatan BIAk, pendamping BIA menggunakan buku panduan yang berjudul “Aku sahabat Yesus Tahun” yang memiliki seri tahun A, B, C, yang penggunaannya menyesuaikan tahun liturgi Gereja.

Setelah pandemi covid-19, Paroki St. Perawan Maria dari Gunung Karmel, Malang mengadakan kegiatan BIAK-nya menggunakan bantuan media online. Media online yang digunakan adalah menggunakan media Youtube. Pada kesempatan/momen tertentu, kegiatan dilangsungkan dengan menggunakan media "Zoom meeting" atau "Google Meet". Keduanya ini adalah aplikasi yang menyediakan sarana untuk berkomunikasi yang menampilkan gambar dan suara secara bersamaan.

Dalam hal waktu pelaksanaan BIAK, kegiatan ini juga sama-sama dilaksanakan pada hari minggu, yaitu setiap minggu pertama sampai dengan minggu ketiga. Pada minggu keempat, 
kegiatan BIAK diliburkan, agar peserta BIAK mendapat kesempatan untuk mengalami kebersamaan dengan orangtua. Apabila dalam bulan itu memiliki minggu kelima, maka pada hari minggu kelima, peserta BIAK dapat mengadakan misa bersama dengan orangtuanya.

Kegiatan BIAK online berlangsung sekitar 20-30 menit. Kegiatan tersebut didampingi oleh enam Orang yang terdiri dari Suster Novisiat H. Carm, suster PIJ, frater, dan pembina awam, dengan sistem semua pembina terlibat. Menurut pembina, kendala yang dihadapi setiap kali melangsungkan kegiatan BIAK ini adalah kuota internet yang tidak ada, jaringan internet yang buruk dan juga kurangnya kesadaran dari para orangtua untuk mendampingi anak mengikuti kegiatan BIAK.

Struktur kegiatan BIAK dilakukan hampir sama dengan kegiatan BIAK sebelum pandemi, yaitu: Sapaan awal, gerak dan lagu pembuka, doa pembukaan, bacaan Injil (mengikuti bacaan injil pada hari itu), renungan, aktivitas/kreativitas (yang mengacu pada catatan sigal) (FX. Galix Wira Hadi, 2021), sapaan penutup, berkat imam (secara daring ), dan lagu penutup.

Tentu masih banyak kekurangan. Hal ini karena masih diperlukan relasi/interaksi dua arah untuk perkembangan iman anak. Selama masa pandemi, mungkin langkah yang terbaik adalah dengan menyusun pedoman acara/kegiatan BIAK online secara sistematis. Tentunya dengan memperhatikan unsur iman dan unsur-unsur yang menarik perhatian anak dalam mendengarkan, menonton sajian BIAK yang telah dipersiapkan oleh pembina BIAK atau

\section{KESIMPULAN}

Kehadiran pandemi covid-19 telah membawa pengaruh yang besar bagi kehidupan manusia, khususnya Gereja sendiri. Bagi Gereja sendiri, pengaruh yang dirasakan adalah berubahnya kegiatan umat beriman yang biasanya dilangsungkan secara tatap muka, kini menggunakan media daring atau online. Akibat dari kebijakan ini adalah kegiatan umat beriman menjadi terhambat. Salah satu aktivitas umat beriman yang menjadi dampak Covid-19 ini adalah kelompok kategorial BIAK.

BIAK adalah merupakan singkatan dari Bina Iman Anak Katolik. Kegiatan ini memiliki tujuan agar anak-anak dapat memiliki sikap dan wawasan iman Kristiani, dan mampu mengungkapkan imannya, serta dapat mewujudkan imannya di dalam kehidupan sehari-hari. Subyek utama dari kegiatan BIAK ini adalah anak itu sendiri, yang berusia 1-12 tahun.

Kegiatan BIAK ini terbentuk dari kesadaran dan perhatian Gereja terhadap kaum muda, khususnya anak-anak. Selain itu, kegiatan atau kelompok ini didasarkan pada ajaran Yesus yang terdapat pada Injil Lukas 18:15-17. Berdasarkan teks tersebut, Yesus mengajarkan bahwa anakanak adalah gambaran Kerajaan Surga. Dengan begitu, pengikut Kristus haruslah memberikan perhatian kepada mereka.

BIAK memiliki ciri khas, yaitu kegiatannya berlangsung dalam suasana gembira. Dalam prosesnya, kegiatan ini menggunakan berbagai metode seperti menyanyi bersama, bermain, mendengarkan cerita, berdoa kegiatan kreativitas, kunjungan karya wisata dan lain sebagainya. Penggunaan metode ini diharapkan dapat membantu anak-anak untuk mengenak Yesus Kristus dan kehendak-Nya pada usia dini. Singkatnya, metode pembinaan iman anak adalah sebuah cara atau jalan yang dipakai untuk mencapai tujuan pembinaan iman anak, yaitu mengenal Tuhan Yesus dan kehendak-Nya.

Gereja memiliki sikap mendengarkan, khususnya dalam situasi pandemi Covid-19. Sikap itu diwujudkan dengan mengarahkan pandangannya terhadap kemajuan teknologi internet. Gereja melihat peluang bahwa internet dapat digunakan sebagai sarana evangelisasi dan katekese. Hal ini 
juga dapat dilakukan untuk menghidupkan kembali kegiatan BIAK yang sempat terhambat prosesnya, sejak munculnya pandemi Covid-19.

Peluang mengenai internet tersebut sudah diwujudkan dalam kegiatan BIAK di Paroki St. Perawan Maria dari Gunung Karmel. Di Paroki tersebut, BIAK dilaksanakan secara online /daring . Sejak pelaksaannya terdapat hal yang berbeda dan juga sama. Persamaannya adalah terletak pada materi yang disampaikan, dan struktur pendampingan. Sedangkan perbedaannya terdapat pada tempat pelaksanaan BIAK. BIAK sebelum pandemi dilaksanakan di aula Gereja, sedangkan BIAK online dilaksanakan menggunakan sarana media online, yaitu Youtube. Selain itu, perbedaan lain juga ditemui dari waktu berlangsungnya kegiatan tersebut. BIAK sebelum pandemi berlangsung sekitar 1 jam 30 menit, sedangkan BIAK online berlangsung sekitar 20-30 menit. Melihat semua perubahan ini, kegiatan BIAK menampilkan wajah barunya. BIAK saat ini berubah wajah dari offline/tatap muka, kini menjadi online /daring . Hal ini juga menunjukkan bahwa kegiatan BIAK semakin lebih modern.

\section{DAFTAR PUSTAKA}

Albi Anggito, J. S. (2018). Metodologi penelitian kualitatif. CV Jejak (Jejak Publisher). Antonius Tse. (2014). Pendidikan Anak Usia Dini. Madiun: Wina Press.

Bernadeta Harini Tri Prasasti (Ed.), Andreas Suparman (Penerj.). (2019). Communio et Progressio (Instruksi Pastoral tentang alat-alat komunikasi Sosial yang diterbitkan sesuai arahan Konsili Ekumenis Vatikan II). Jakarta: Dep. Dokpen KWI.

Dokumen Konsili Vatikan II. (1990). Terang Bangsa-bangsa: Konstitusi Dogmatis tentang Gereja [Judul Asli: Lumen Gentium] (Hardawiryana R, Penerj.). Jakarta: Dep. Dokpen KWI.

Dokumen Konsili Vatikan II. (1992). Kegembiraan dan Harapan [Judul Asli: Gaudium et Spes] (Hardwirayana R., Penerj.). Jakarta: Dep. Dokpen KWI.

Yoyo Sudaryo, S. E. M. M. A. C. A. A., Dr. Nunung Ayu Sofiati, S. P. M. M., R. Adam Medidjati, S. E., \& Dr. Ana Hadiana, M. E. S. (2019). Metode Penelitian Survei Online dengan Google Forms. Penerbit Andi. Diambil dari https://books.google.co.id/books?id=u7ChDwAAQBAJ

Fajria Anindya Utami. (2020, Mei 19). Apa itu New Normal [Berita]. Diambil 17 April 2021, dari Warta Ekonomi website: https://www.wartaekonomi.co.id/read286203/apa-itu-newnormal\#: :text=New\%20normal\%20adalah\%20sebuah\%20perubahan,untuk\%20mengha dapi\%20penyebaran\%20virus\%20corona.

Bagiyowinadi, FX Didik. (2009). Bekal Pendampingan Bina Iman Anak. Yogyakarta: Yayasan Pustaka Utama.

FX. Galix Wira Hadi. (2021). Bahan Kreativitas Pendampingan Iman Anak [Blog]. Diambil dari Catatan Sigal website: http://www.catatansigal.com/

Lebo Diseko. (2020, Maret 11). Virus corona: Apa dampak Covid-19 terhadap tata cara ibadah agama?" [Berita]. Diambil 14 April 2021, dari BBC News Indonesia website: https://www.bbc.com/indonesia/indonesia-51813486

Maria Goretti Sugiarti AK (Ed.). (1999). Pendampingan Iman Anak (Diktat). Yogyakarta:

Fakultas Ilmu Pendidikan Agama-Universitas Sanata Dharma.

Mestika Zed. (2014). Metode Penelitian Kepustakaan. Jakarta: Yayasan Pustaka Obor Indonesia. Paus Yohanes Paulus II. (2004). Keluarga: Peranan Keluarga Kristen dalam Dunia Modern [Judul Asli: Familiaris Consortio] (Hardawiryana R., Penerj.). Jakarta: Dep. Dokpen KWI. 
Paus Yohanes Paulus II. (2006). Penyelenggaraan Katekese [Judul Asli: Catechesi Tradendae] (Hardawiryana R., Ed.). Jakarta: Dep. Dokpen KWI.

Pusat Kateketik. (2002). Kursus Pendampingan Iman Anak Bagi Para Novis dan Postulan Yogyakarta. Yogyakarta: IPPAK.

Rehia Sebayang. (2020, Maret 12). WHO Nyatakan Wabah COVID-19 jadi Pandemi, Apa Maksudnya? [Berita]. Diambil 17 April 2021, dari CNBC Indonesia website:https://www.cnbcindonesia.com/news/20200312075307-4-144247/who-nyatakanwabah-covid-19-jadi-pandemi-apa-maksudnya Sugiyono. (2013). Metode Penelitian Pendidikan Pendekatan Kuantitatif Kualitatif, dan $R \&$ D. Bandung: Alfabeta.

Selatang, F., \& Neonbasu, J. (2020). BIAK: Ruang Interaksi Sosial antar Penyandang Disabilitas. Jurnal Pelayanan Pastoral, 1(1), 16-24. 